\title{
STUDY OF THE CURRENT AND HISTORIC \\ NATURAL RESOURCES OF THE FORT \\ UNION TRADING POST NATIONAL \\ HISTORIC SITE
}

\author{
K. M. Weist \\ Department of Anthropology \\ P. B. Wilson \\ Department of Geography \\ J. H. Lowe \\ E. E. Willard \\ School of Forestry \\ University of Montana
}

\section{Objectives}

Fort Union Trading Post was one of the largest and most important fur posts on the Upper Missouri, described by Hiram Chittenden as "...the best built post on the Missouri, and with the possible exception of Bent's fort on the Arkansas, the best in the entire West" (1954:2:959). Fort Union was an important focal point for the Assiniboine, Cree, and Crow tribes who came there to trade, receive their annuities, and learn about White activities. The financial success of the post depended upon the hunting and trapping efforts of these Indians, who brought in bison robes and other animal pelts to trade for White-make goods. Thus, the success of the post was directly related to the natural resources of the area. Our research describes these resources-the mammals, reptiles, birds, insects and plants--both at the present time (1979) and historically.

The research project consists of three separate but interrelated phases: 1) an inventory of the historic flora and fauna, 2) a description of the contemporary animal and plant communities, and 3 ) the construction of a set of maps of the data collected.

The historical portion of this project is an inventory, to the extent permitted by the available information, of the natural resources of the Fort Union area during the decades of the 1840's and 1850's. These were the decades during which the post reached its peak and the target periods for its reconstruction. These decades were also the ones during which many noted travelers, traders, missionaries, Indian agents, naturalists, artists and sportsmen visited the post. Because the Fort Union Historic Site covers a relatively small area of approximately 392 acres, the historic data collected have been broadened to include both a greater time span and geographic area.

The Public Land Survey Plats and Notes provide valuable information, particularly on the flora of specific sites along the route of the survey. The plats and notes have been reviewed as part of the archival 
research. Other sources for historical data include an inspection of the paintings by Bodmer, Kurz, Catlin, Stanley and Point. Caution, however, must be used when drawing upon these paintings as a data source because frequently the artists took liberties when depicting the natural environment.

Descriptions of the contemporary natural resources are restricted to the Fort Union Trading Post Site. Each plant community has been described and maps of the present communities are being constructed. In addition, a narrative has been developed to describe the potential or "climax" vegetation on each site.

Maps have been prepared which show the flora and fauna of the Fort Union Site as it exists at the present and as it existed during the 1840 's through 1850 's. Additional maps are also being prepared which show the natural scene of the larger. region surrounding Fort Union in the $1840^{\prime} \mathrm{s}$.

\section{Methods}

The historic portion of the project involved library research of journals, diaries, reports, letters and surveys written by those who visited the fort and nearby areas during the period under study. The majority of these works are located in the University of Montana Library, which holds a large collection of Western Americana. The Public Land Survey records were of value because they allowed for the placement of specific plants at specific locations within the Fort Union Site as of the date of the survey. The data abstracted from these documents were recorded on a form especially constructed for this project. These data include when the flora and fauna were observed, where they were located, the nature of the populations or communities and the behavior of the fauna. Based upon this information, the historic flora and fauna, their habitats and the diversity of habitats have been reconstructed where possible.

The present animal, insect and bird species have been identified when possible in order to determine their present habitats and the habitat requirements of the various fauna. A plant species list has been developed for each community, along with the percentage of each species within the total community. Plant species composition (\% of each species of the total) is expressed as percentage by weight. Weight was determined by standard methods, including clipping and weighing, supplemented by occular estimates. A list of exotic plant species in each community will be included in the report.

The local Soil Conservation Service was contacted to obtain soils maps and data for the site. The soils serve as a guide to the potential plant communities. The soil Conservation Service descriptions of climax range sites on each soil type serve as a base from which to judge the potential vegetation.

Results 
The natural vegetation of the upland sites is typical of the Mixed Prairie. Descriptions of the vegetation may be found in Hanson and Whitman (1938), Payne (1973), Coupland (1950), and Quinnild and Cosby (1958). However, the natural variability of vegetation from one site to another dictates that these descriptions be refined for specific sites. In attempting to reconstruct the natural vegetation of the Fort Union Trading Post site, searches were made of the local area for relatively undisturbed sites, along with relicts of natural vegetation. Ten such sites were observed. However, sufficient evidence is available in the literature and on undisturbed sites around Fort Union to develop a reasonably accurate list of plant species which would occupy each distinct site.

The Fort Union Trading Post site contains eight ecologically distinct potential plant communities. These have been deliniated on a map of the site which will be included in the final report.

The vegetation around Fort Union would have been in a rather advanced stage of disturbance during the period of its operation. Historic records indicate that numerous horses and cattle were kept by the traders at the fort. Also, the Indians camped on the grounds near the fort would have contributed significantly to the disturbance through normal trampling and wood-gathering activities and from the grazing of their horses.

Weber (1859) mentioned that both milk cows and work cattle were kept at the fort. Catlin (1913) recorded that at the time he visited Fort Union there were about one hundred and fifty horses at the fort. Prince Maximilian (1906) reported that the fort (1833-1834) contained "about fifty or sixty horses, some mules, and an inconsiderable number of cattle, swine, goats, fowls, and domestic animals. The cattle are very fine, and the cows yield abundance of milk. The horses are driven, in the day time, into the prairie, guarded and exercised by armed men, and, in the evening, brought back into the quadrangle of the fort, where the greater part of them pass the night in the open air."

The disturbed condition of the vegetation is further expressed by the abundance of cactus in the area. Denig, in his journals as edited by Ewers (1961) recorded that "the principal hinderance to foot travelers in this district is the innumerable family of cacti, some of which are armed with very long and strong points and ruin the feet of anyone walking without strong soles to his shoes." Maria Audubon (1960) recorded the diary of James Audubon (1897) who also visited Fort Union. He wrote that there were "many Cacti of two sorts" and that "the prairie is covered with cacti." Willard and Herman (1977) found that prickly-pear cactus (Opuntia polyacantha) increases with excessive grazing in eastern Montana.

Only one photograph has been found of the fort, and this was taken in 1866 by A.J. Fisk one year before the fort was abandoned. Only two plant species can be seen in the photograph. These are Artemisia 
frigida and Circium arvense, two perennial forbs well known to invade or increase under excessive grazing. These two species are still found at the fort, but in minor amounts.

The present vegetation at Fort Union is a mixture of plant communities and cultivated lands. The plant communities will be shown on a map in the final report. Altogether, thirty-one different vegetation types were mapped on the area; plant species and percentages of each will be listed in the final report.

Numerous plant species not native to North America are present on the Fort Union Trading Post site. These are listed in Table 1.

Table 1. Exotic Plant Species on the Fort Union Trading Post Site.

\begin{tabular}{|c|c|c|}
\hline Grasses & Forbs & Trees and Shrubs \\
\hline $\begin{array}{l}\text { Agropyron cristatum } \\
\text { Agrostis alba } \\
\text { Bromus inermis } \\
\text { Bromus japonicus }\end{array}$ & $\begin{array}{l}\text { Kochia scoparia } \\
\text { Medicago sativa } \\
\text { Melizotus officinalis } \\
\text { Tragopogon dubius }\end{array}$ & $\begin{array}{l}\text { Eleagnus angustifolia } \\
\text { Robinia pseudoacacia }\end{array}$ \\
\hline
\end{tabular}

Much of the site has been placed in cultivation, some areas are not cultivated but are in various stages of disturbance, while other areas contain natural vegetation. Areas of natural vegetation should be protected from disturbance. No further modifications are necessary. All other areas will require drastic modifications to return the vegetation to a natural mixture of species.

A review of the early diaries, books, and other documents of the Fort Union era has produced extensive lists and descriptions of the flora and fauna of the period. From the explorations of Lewis and Clark, the first whites to record their observations of the area, to the close of the fur trade on the Upper Missouri, Fort Union was visited by a number of naturalists--botanists, geologists, and zoologists--who described the flora and fauna. The most important were Meriwether Lewis, William Clark, Thomas Nuttall, John Bradbury, John J. Audubon, Edward Harris, and Ferdinand V. Hayden. Other observers of less importance were George Catlin, Prince Maxmilian du Weid, and the members of the Northern Pacific Railroad Survey. The findings of the primary observers will be listed in the final report.

\section{Conclusions}

The Fort Union area, at the confluence of the Missouri and Yellowstone 
Rivers, was a site rich in flora and fauna. The vegetation of the site has been greatly altered, so that much of the area is in cultivation, is composed mainly of exotic species, or is in some seral stage removed from the climax vegetation. However, the soil is essentially intact, and there is no indication that any of the native plant species are extinct. Therefore, with time, the vegetation can be reconstructed on the site.

Disturbance of the fauna has been much more severe, Several species, including the grizzly, wolf, bison, elk, Audubon bighorn sheep, and black-footed ferret, are gone from the area. These and other lessobvious species can probably never be returned to the area in a natural state. The Audubon bighorn sheep is extinct, and the ferret nearly so.

\section{Literature Cited}

Audubon, Maria R. 1960. Audubon and His Journals. Notes by Elliott Coues, 2 vols. New York: Dover Publications.

Catlin, George. 1913. Native American Indians, Being Letters and Notes 1832-1839. 2 vols. Philadelphia: Leary, Stuart \& Company

Coupland, R.l. 1950. Ecology of Mixed Prairie in Canada. Ecological Monographs 20:273-315.

Denig, E.T. 1961. Five Indian Tribes on the Upper Missouri. University of Oklahoma. Press, Norman.

Fisk, James L. 1866. Expedition from Fort Abercrombie to Fort Benton. 37th Congress, 3rd Session, House Executive Document 80, Serial 1164.

Hanson, H.C. and W. Whitman. 1938. Characteristics of Major Grassland Types in Western North Dakota. Ecological Monographs 8:57-114.

Maximilian, Prince Paul de Neuweid. 1960. Travels in the Interior of North America, 1832-1834. In Early Western Travels, Rueben G. Thwaites, ed. vols 22-25. Cleveland: Arthur H. Clark Company.

Payne, G.F. 1973. Vegetative Rangeland Types in Montana. Montana Agri. Expt. Sta., Bozeman Bull. No. 671. 15pp.

Quinnild, C.L. and H.E. Cosby. 1958. Relicts of Climax Vegetation on Two Mesas in Western North Dakota. Ecology 39:29-32.

Weber, C.H. 1859. Journal of a Trip to Fort Benton on Board the "Spread Eagle" May 28 to August 16, 1859. Library of Congress.

Willard, E.E. and L. Herman. 1977. Grazing Study in the Missouri Breaks. Montana Forest and Conservation Experiment Station, Bureau of Land Management Special Report. $77 \mathrm{pp}$. 